Orissa Journal of Commerce

Vol. 42, Issue 2, April-June 2021

ISSN: 0974-8482

(c) OJC India. All Right Reserved

URL: www.ojcoca.org

DOI: https://doi.org/10.54063/ojc.2021.v42i02.01

\title{
Network Relationships in Knowledge Based Service Firms: Variance in Terms of Firm Size
}

\author{
Amit Sareen ${ }^{1 *}$ and Sharadindu Pandey ${ }^{2}$ \\ ${ }^{1}$ Dean (Academics), Institute of Management Technology, Ghaziabad, India. E-mail: amit.sareen@imt.edu \\ ${ }^{2}$ Assistant Professor, Indian Institute of Forest Management, Bhopal, India. E-mail: dsp.gbu@gmail.com \\ ${ }^{*}$ Corresponding Author
}

To cite this paper

Sareen, A., \& Pandey, S (2021).

Network Relationships in

Knowledge based Service Firms:

Variance in Terms of Firm Size.

Orissa Journal of Commerce. 42(2), 1 -

13.

Keywords

Network relationships, Firm size, Customer networks, Supplier networks, Competitor networks, Investor networks

JEL Classification

M10, M13, M20, O31, O32

\begin{abstract}
Networks are critical in the growth of knowledge intensive business services (KIBS) and include networks with service providers, suppliers, competitors, customers and investors. The research evaluates the variance of network relationships in terms of firm size and involved cross sectional survey of KIBS firms in India. Firms were classified into four groups in terms of number of employees: up to $100 ; 101$ to $1000 ; 1001$ to 10,000; and with above 10,000 employees. The study finds there is a significant difference in network relationships with customers and investors for firms with above 10000 employees as compared to firms with upto 100 employees. At the same time no difference across firms of different sizes is found in terms of network relationships with suppliers and competitors. The study also finds that as a firm crosses the threshold of 100 employees, network relationships across different groups do not have differences that are significant.
\end{abstract}

\section{Introduction}

Business organizations have network relationships with other firms. Networks allow access to knowledge and organizational resources and this is further facilitated by social interactions between members of partner organizations (Inkpen and Tsang, 2005). Thus it is imperative for firms to collaborate to gain knowledge as knowledge markets are rare (Huggins, 2010). Innovation is a product of network of actors and firms do not innovate in isolation (Arias, 1995; Huggins, 2010). Explicit knowledge is easier to transfer but networks play a particularly important role in transfer of tacit knowledge which is more difficult to transfer (Hertog, 2000).

Networks may also serve as a good source of ideas for innovation (Sundbo, 1997) and such network relationships may facilitate service innovation (Yung-Chang, 2019). While past approaches have focused on isolated problem solving, there is a need to reorient our thinking towards systems, networks and ecosystems (Barile, 2016). The focus of this study is on how network relationships vary with firm size in KIBS in India. 
Amit Sareen and Sharadindu Pandey

A firm may have different network relationships such as those with service providers, suppliers, competitors, customers and investors. In the research, number of employees measures firm size and firms are categorized as those with: 1-100; 101-1000; 1001-10000; and 10001 or above employees.

The study gives insights into network relationships for firms of different sizes as such relationships foster innovation and introduction of new services particularly when we are considering KIBS. Also instead of a one size fits all strategy, KIBS firms of different sizes need to develop and evolve a networking strategy most suitable to the size of the firm.

\section{Review of Literature}

\subsection{Network Relationships}

Small enterprises are risk averse and intolerant towards uncertainties (Laforet, 2012). The knowledge provided through strong relationships help KIBS firms to innovate and thus bring about new products or services (Amara et al., 2009). Innovative strategic decisions are made by firms as they access knowledge through business and social networks (Wulf and Butel 2017). Innovative partners for inter-firm cooperation include customers, suppliers, competitors, producers and service providers (Zeng et al., 2010). Network types include networks with customers, suppliers, investors, competitors, universities \& research institutions and government agencies \& regulators (Pittaway et al., 2004). Sareen and Pandey (2014) found that in the case KIBS firms in the Indian context, the network relationships with universities \& research institutions and government $\&$ regulatory agencies are weak and thus need not be considered.

The cooperation can extend both upstream with suppliers and downstream with customers (Walters and Rainbird, 2007). Network intensity may be described as the frequency of communication between network partners (Xu et al., 2008). Increasing use of information technology and digital platforms facilitates and fosters network relationships with partner organizations. In firms which have strong network relationships, employees of the respective firms may work together as if they are in the same workgroup (Amara et al., 2009). Needs expressed by customers or supplier proposals or ideas from competitors may spur firm level innovation (Chang et al., 2012). High tech firms can co-create relationship advantages by integrating resources through business relationships (Park and Lee, 2018).

Since knowledge and information may reside in computers, information systems, documents, practices, thus knowledge exchange between two firms is a complex process (Landry et al., 2012). It is important for the customers to participate in the entire cycle of the innovation process (Chesbrough, 2011). The line between producers and consumers is increasingly getting blurred (Michel et al., 2008). Client relationships play a central role in innovation in KIBS firms (Santos-Vijande et al., 2013). Customers could be considered as a resource, co-creators and users (Nicolajsen and Scupola, 2011).

Collaboration with suppliers is important in driving innovation (Henke Jr. and Zhang, 2010). Many times while developing innovative products and services, firms need to work with suppliers from the design stage itself. Strong network relationships with suppliers helps generate trust as many times project specifications and details need to be shared with suppliers. Service firms may gain knowledge and technology through suppliers (Tether, 2005; Rusanen et al., 2014). Collaboration with 
Network Relationships in Knowledge Based Service Firms: Variance in Terms of Firm Size

suppliers is particularly important for developing be-spoke solutions. The roles of suppliers is important when we consider technological innovation (Hertog, 2000).

Many companies have not been able to work together to tackle complex challenges due to competitive self-interest (Nidumolu et al., 2014). The performance of a business is also dependent on the external environment and to meet external environmental challenges, firms may need to work together with competitors to build an appropriate response. Collaborating with competitors always carries certain risk and this may reduce the level of collaboration between two firms (Miotti and Sachwald, 2003). Thus firms may have network relationships with only select competitors with whom they are able to develop trust. Firms may also need to work together with competitors as a part of a global alliance or for executing large projects, which may involve multiple vendors.

Firms may also develop network relationships with strategic investors. Such investors may bring appropriate knowledge and insights from the outside world as they have a stake in the success of the firm. Many of the KIBS firms are privately owned or have investors who have substantial stake in the firm and such investors play an important role in deciding firm strategy and growth related decisions.

\subsection{Impact of Firm Size on Network Relationships}

Large firms have more resources to conduct research and innovate. Freel and Harrison (2006) suggest that firm size could be a proxy for accumulated resources. Smaller firms are risk averse and would like to avoid ambiguity (Laforet, 2012). The larger firms can spend more resources and are also able to achieve economies of scale (Amara et al., 2009). While the large firms may be able to maintain a diverse portfolio of projects and products, the smaller firms have the advantage of making faster decisions as they are less bureaucratic and have higher flexibility (Pires et al., 2008). Company size may provide a sustainable environment for innovations and large firms may be able to innovate their supply chains and financial models (Aguilar-Fernández et al., 2018). Firms which are older may benefit more from their relationships with research organizations (Yu and Lee, 2017). Larger firms may have an advantage when one considers continuity of exports in global supply chains (Bandick, 2020). When one considers the social and environmental performance of a firm, then one finds that there is a positive linkage with firm size (Wang et al., 2018). In case of larger firms, the promoters may follow a low risk and high innovation strategy, while in case of smaller firms the promoters may follow a high risk and low innovation strategy (Marom et al., 2019). A firm pursuing a higher level innovation strategy would require stronger network relationships with its partner firms. Network level resources positively impact firm innovation (Demirkan, 2018). In case of small and medium enterprises there is a positive linkage between firm size and the performance of the firm (Tang et al., 2020).

\section{Objective and Hypotheses of the Study}

\subsection{Objective}

The key objective of the study is to evaluate whether network relationships vary in terms of firm size in the case of KIBS firms in India.

Orissa Journal of Commerce, 42(2) (C) 2021 
Amit Sareen and Sharadindu Pandey

Network relationships include those with investors, select competitors, customers and suppliers. Firm size is measured in terms of the number of employees in the firm. The study provides insights into how network relationships vary with firm size. Such insights may help firms to develop effective strategies to enhance their network relationships.

\subsection{Hypotheses}

Sareen and Pandey (2015) have developed and defined the constructs and the scale for measuring network relationships in terms of: Network. Relationship with Suppliers (NS), Network Relationship with Investors (NI), Network Relationship with Customers (NC), and Network Relationship with Select Competitors (NCOM). Based on review of literature and the constructs defined, the following hypotheses have been proposed:

$\mathbf{H}_{01 a}:$ There is a significant difference in NC of firms with above 10000 employees and firms with upto 100 employees.

$\mathbf{H}_{01 \mathrm{~b}}$ : There is a significant difference in $\mathrm{NC}$ of firms with above 10000 employees and firms with 101-1000 employees.

$\mathbf{H}_{02 \mathrm{a}}:$ There is a significant difference in NS of firms with above 10000 employees and firms with upto 100 employees.

$\mathbf{H}_{\mathbf{0 2}}$ : There is a significant difference in NS of firms with above 10000 employees and firms with 101-1000 employees.

$\mathbf{H}_{03 \mathbf{a}}$ : There is a significant difference in NCOM of firms with above 10000 employees and firms with upto 100 employees.

$\mathbf{H}_{03 \mathbf{b}}$ : There is a significant difference in NCOM of firms with above 10000 employees and firms with 101-1000 employees.

$\mathbf{H}_{04 a}$ : There is a significant difference in NI of firms with above 10000 employees and firms with upto 100 employees.

$\mathbf{H}_{04 \mathbf{b}}$ : There is a significant difference in NI of firms with above 10000 employees and firms with 101-1000 employees.

\section{Research Methodology}

\subsection{Research Design}

The study aims to evaluate the impact of firm size on network relationships in the context of KIBS firms in India. The study adopted a single cross-sectional research design and has focused on firms across the spectrum of KIBS. The firm sizes varied from organizations with upto 100 employees to organizations with more than 10000 employees. Validity and reliability of the research instrument has been tested through a thorough review process by industry and academic experts and then through factor analysis. 


\subsection{Sampling Adequacy}

Adequacy of the sample was tested through the Kaiser-Meyer-Olkin (KMO) test (Kaiser, 1974). The $\mathrm{KMO}$ value above 0.8 indicates that the sample size is adequate. Sampling adequacy can be arrived at by measuring KMO statistics (Pallant, 2013). Bartlett's test of sphericity is a statistical test for presence of correlation among variables (Bartlett, 1950) and is able to indicate any significant correlations among variables under consideration (Hair et al., 2006). In the study it is found that Bartlett's test is significant $(\mathrm{p}=.000)$.

\subsection{Conceptual Framework}

The Conceptual Framework of the study is provided in Figure 1:

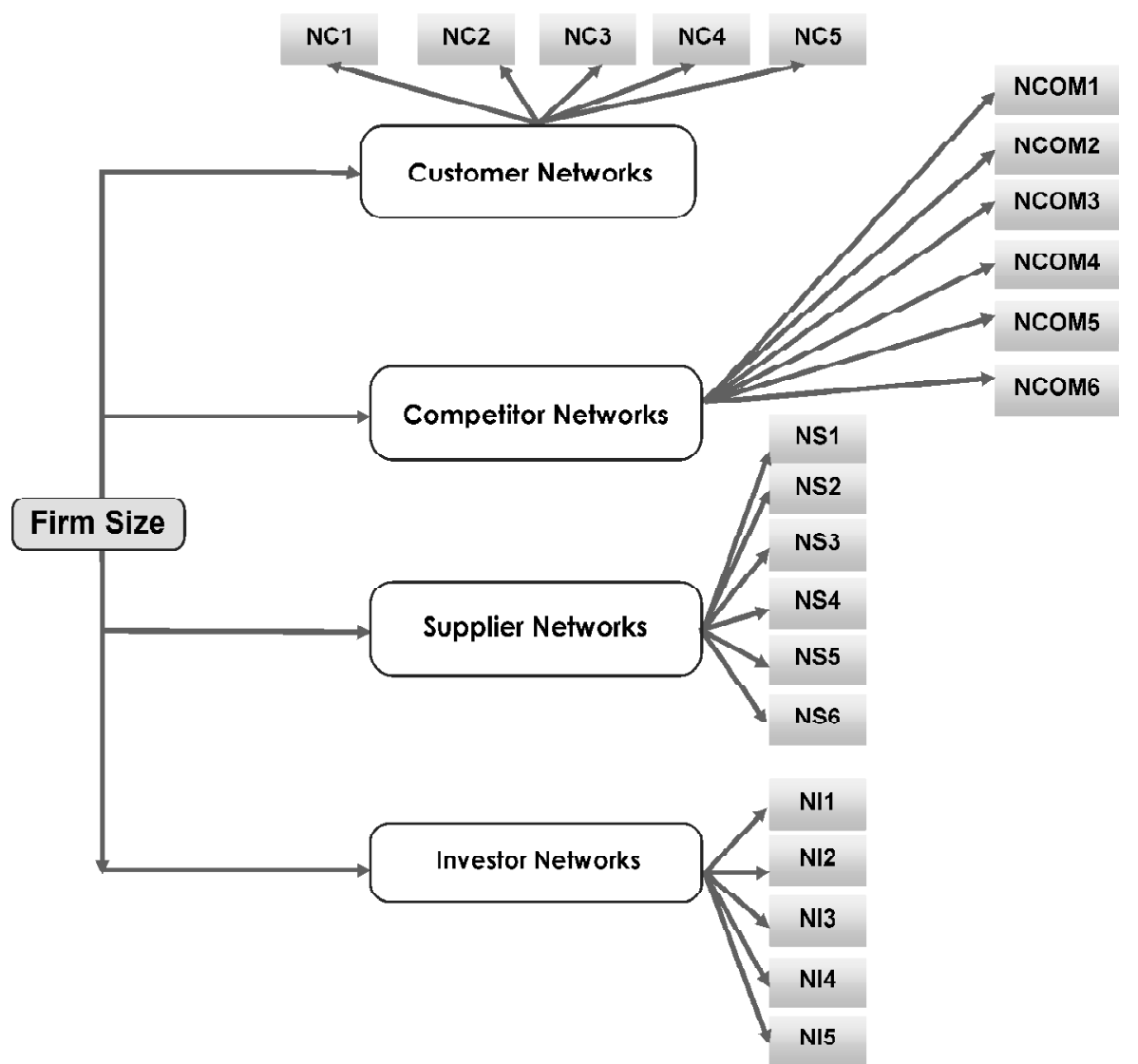

Figure 1: Conceptual Framework

Note: The above figure is authors' own compilation. The constructs for measuring different aspects of networks have been adapted from Sareen and Pandey (2015). 
Amit Sareen and Sharadindu Pandey

\subsection{Firm Groupings}

To evaluate the impact of firm size on different network relationships, ANOVA analysis has been done in terms of 4 groups. Firms with employee strength (Emp) of: 1 to 100 belonged to Group 1; 101 to 1000 belonged to Group 2; 1001 to 10000 belonged to Group 3; and 10001 or above belonged to Group 4.

\subsection{Data Collection}

A personalized email was sent to 687 respondents summarizing the objectives of the study and subsequently a web based questionnaire was sent to those respondents who showed interest in the study. Finally, 172 completed responses were received. On final review of the responses only 151 valid responses were found and this represented a response rate of $22 \%$. The conceptual framework of the study is provided in Figure 1.

\section{Data Analysis and Discussion}

\subsection{Network Relationship with Customers}

Firms develop relationships with customers who are an important source of information for innovative activities. The items (NC1 to NC5) constitute the construct Network Relationship with Customers (NC) and Table 1 provides the mean scores and standard deviations for each of the items. The mean score of 4.01 for NC suggests strong relationship with customers.

Table 1: Mean Scores and SD of Network Relationship with Customers

\begin{tabular}{llrr}
\hline Variable & Description & Mean & SD \\
\hline NC1 & We maintain regular communication with our customers & 4.4371 & .65905 \\
NC2 & We fully understand the needs expressed by our customers & 4.2583 & .73452 \\
NC3 & Customers provide detailed specifications for new services & 3.5629 & .94217 \\
NC4 & Customers regularly provide feedback and suggestions for & 3.6821 & .91921 \\
& improvement & 4.1391 & .77494 \\
NC5 & We frequently exchange knowledge with our clients & 4.0159 & .62760 \\
NC & & &
\end{tabular}

Source: Authors' own compilation

Notes: The construct 'Network Relationship with Customers' has been defined by Sareen and Pandey (2015)

Table 2 describes the analysis of variance of the variable $\mathrm{NC}$ with respect to firm size. It is observed that the differences between groups are significant $(\mathrm{p}<.05)$.

Table 3 presents multiple comparisons among different groups for the variable NC. In Table 3, it may be observed that there is a statistically significant difference between Group 4 and Group 1. Thus network relationship with customers is stronger for firms belonging to Group 4 as compared to firms 
Network Relationships in Knowledge Based Service Firms: Variance in Terms of Firm Size

Table 2: Analysis of Variance of NC by Firm Size

\begin{tabular}{lrrrrr}
\hline & Sum of Squares & $d f$ & Mean Square & $F$ & Sig. \\
\hline Between Groups & 4.181 & 3 & 1.394 & 3.731 & .013 \\
Within Groups & 54.901 & 147 & .373 & & \\
Total & 59.082 & 150 & & & \\
\hline
\end{tabular}

Source: Authors' own compilation

in Group 1. This shows that the hypothesis $H_{01 a}$ is accepted. As firms increase in size network relationships with customers become stronger although in Table 3, it is observed that there is no significant difference in NC between Group 4, Group 3 and Group 2. This implies that the hypothesis $H_{01 b}$ is rejected.

Table 3: Multiple Comparisons of NC by Firm Size

\begin{tabular}{rrrrrrr}
\hline (I) Emp & Mean & & & \multicolumn{2}{c}{ 95\% Confidence Interval } \\
& & Difference (I-J) & Std. Error & Sig. & Lower Bound & Upper Bound \\
\hline 1 & 2 & -.37224 & .16216 & .158 & -.8309 & .0864 \\
& 3 & -.22094 & .15447 & .564 & -.6578 & .2159 \\
& 4 & $-.37157^{*}$ & .11812 & .022 & -.7056 & -.0375 \\
2 & 1 & .37224 & .16216 & .158 & -.0864 & .8309 \\
& 3 & .15130 & .18685 & .883 & -.3771 & .6797 \\
& 3 & .00068 & .15813 & 1.000 & -.4465 & .4479 \\
3 & 4 & .22094 & .15447 & .564 & -.2159 & .6578 \\
& 1 & -.15130 & .18685 & .883 & -.6797 & .3771 \\
& 2 & -.15063 & .15023 & .800 & -.5755 & .2742 \\
& 4 & $.37157^{*}$ & .11812 & .022 & .0375 & .7056 \\
4 & 1 & -.00068 & .15813 & 1.000 & -.4479 & .4465 \\
& 2 & .15063 & .15023 & .800 & -.2742 & .5755 \\
& 2 & & & & &
\end{tabular}

Source: Authors' own compilation

Notes: * .05 level is taken for significance in the Mean Difference

\subsection{Network Relationship with Suppliers}

Suppliers are an important source of information in firms. Table 4 presents the mean scores and SD for the items (NS1 to NS6) constituting the construct Network Relationship with Suppliers (NS). The mean score of NS is 3.60 .

Table 5 describes the analysis of variance of the variable NS with respect to firm size. It is observed that the differences between groups are not significant. Thus there is no significant difference 
Amit Sareen and Sharadindu Pandey

in supplier relationships across different firm sizes. Thus both the hypotheses, $H_{02 a}:$ There is a significant difference in NS of firms with above 10000 employees and firms with upto 100 employees \& $H_{026}$ : There is a significant difference in NS of firms with above 10000 employees and firms with 101-1000 employees, are rejected.

Table 4: Mean Scores and SD of Network Relationship with Suppliers

\begin{tabular}{llrr}
\hline Variable & Description & Mean & SD \\
\hline NS1 & We work with our suppliers just as if we are in the same team & 3.6689 & .80599 \\
NS2 & We frequently exchange knowledge with our suppliers & 3.6424 & .83542 \\
NS3 & Our firm regularly takes initiatives to help development of suppliers & 3.5364 & .87769 \\
NS4 & We often work with our suppliers to make joint bids/proposals & 3.4238 & .98953 \\
& to customers & 3.5232 & .90063 \\
NS5 & Our firm often engages in collaborative planning with suppliers & 3.8411 & .80905 \\
NS6 & We maintain regular communication with our suppliers & 3.6060 & .69027 \\
NS & & &
\end{tabular}

Source: Authors' own compilation

Notes: The construct 'Network Relationship with Suppliers' has been defined by Sareen and Pandey (2015)

Table 5: Analysis of Variance of NS by Firm Size

\begin{tabular}{lrrrrr}
\hline & Sum of Squares & $d f$ & Mean Square & $F$ & Sig. \\
\hline Between Groups & 2.371 & 3 & .790 & 1.682 & .174 \\
Within Groups & 69.100 & 147 & .470 & & \\
Total & 71.471 & 150 & & & \\
\hline
\end{tabular}

Source: Authors' own compilation

\subsection{Network Relationship with Select Competitors}

Firms may also develop relationships with select competitors. The items (NCOM1 to NCOM6) constitute the construct Network Relationship with Select Competitors (NCOM). Table 6 provides the mean scores and standard deviations of each of these items. The mean score of NCOM is 2.78 suggesting that KIBS do not have strong relationships with their competitors while at the same time the score of 3.56 for NCOM1 suggests that competitors are a source of new ideas.

Table 7 describes the analysis of variance of the variable NCOM with respect to firm size. It is observed that the differences between groups are not significant. Thus there is no significant difference in competitor relationships across different firm sizes. Thus both the hypotheses, $H_{03 a}$ : There is a significant difference in NCOM of firms with above 10000 employees and firms with upto 100 employees \& $H_{036}$ : There is a significant difference in NCOM of firms with above 10000 employees and firms with 101-1000 employees, are rejected. 
Network Relationships in Knowledge Based Service Firms: Variance in Terms of Firm Size

Table 6: Mean Scores and SD of Network Relationship with Select Competitors

\begin{tabular}{llrr}
\hline Variable & Description & Mean & SD \\
\hline NCOM1 & Select competitors are a regular source of new ideas & 3.5695 & .94875 \\
NCOM2 & Our firm maintains regular communication with select competitors & 2.9801 & .97618 \\
NCOM3 & We frequently exchange knowledge with select competitors & 2.6755 & 1.05546 \\
NCOM4 & We share resources with select competitors in order to & 2.4636 & 1.09407 \\
& complement mutual strengths & 2.5563 & 1.09323 \\
NCOM5 & We work with select competitors to make joint proposals/bids to customers & 2.4834 & 1.09456 \\
NCOM6 & We engage in collaborative planning with select competitors & 2.7881 & .84062 \\
NCOM & & &
\end{tabular}

Source: Authors' own compilation

Notes: The construct 'Network Relationship with Suppliers' has been defined by Sareen and Pandey (2015)

Table 7: Analysis of Variance of NCOM by Firm Size

\begin{tabular}{lrrrrr}
\hline & Sum of Squares & $d f$ & Mean Square & F & Sig. \\
\hline Between Groups & 4.008 & 3 & 1.336 & 1.926 & .128 \\
Within Groups & 101.988 & 147 & .694 & & \\
Total & 105.996 & 150 & & & \\
\hline
\end{tabular}

Source: Authors' own compilation

\subsection{Network Relationship with Investors}

In addition to providing funding, investors may also prove to be good source of knowledge about the competitive scenario and thus the importance of nurturing relationships with investors. Table 8 presents the mean scores and SD for the items (NI1 to NI5) constituting the construct Network Relationship with Investors (NI). The mean score of NI is 3.77 .

Table 8: Mean Scores and SD of Network Relationship with Investors

\begin{tabular}{llrr}
\hline Variable & Description & Mean & SD \\
\hline NI1 & Our firm maintains regular communication with investors & 3.8940 & .98761 \\
NI2 & Investors regularly provide critical information about competitive scenario & 3.5960 & 1.00119 \\
NI3 & We frequently exchange knowledge with our investors & 3.7417 & 1.01629 \\
NI4 & Investors play an important role by providing strategic direction to our firm & 3.6887 & 1.03399 \\
NI5 & We update our investors regularly about significant developments in & 3.9338 & 1.00445 \\
& our business & 3.7709 & .91954 \\
NI & & & \\
\hline
\end{tabular}

Source: Authors' own compilation

Notes: The construct 'Network Relationship with Investors' has been defined by Sareen and Pandey (2015) 
Amit Sareen and Sharadindu Pandey

Table 9 describes the analysis of variance of dependent variable Network Relationship with Investors (NI) with respect to firm size and the difference between the groups is significant. Table 10 presents multiple comparisons among different groups for the variable NI and it is observed that differences between Group 4 and Group 1 as well as between Group 3 and Group 1 are significant. Thus the network relationship with investors is stronger for firms in Group 3 as compared to firms in Group 1. This may be reasoned that as firms become large and the stakes of investors increase in these firms, the investor relationships become stronger. Also, it is observed that with respect to NI, the differences between Group2, Group 3 and Group 4 are not significant. Based on the above observations, the hypothesis $H_{04 a}$ is accepted while the hypothesis $H_{04 b}$ is rejected.

Table 9: Analysis of Variance of NI by Firm Size

\begin{tabular}{lrrrrr}
\hline & Sum of Squares & $d f$ & Mean Square & $F$ & Sig. \\
\hline Between Groups & 9.935 & 3 & 3.312 & 4.165 & .007 \\
Within Groups & 116.897 & 147 & .795 & & \\
Total & 126.832 & 150 & & & \\
\hline
\end{tabular}

Source: Authors' own compilation

Table 10: Multiple Comparisons of NI by Firm Size

\begin{tabular}{|c|c|c|c|c|c|c|}
\hline \multirow{2}{*}{\multicolumn{2}{|c|}{ (I) $E m p$}} & \multicolumn{2}{|l|}{ Mean } & \multirow[b]{2}{*}{ Sig. } & \multicolumn{2}{|c|}{ 95\% Confidence Interval } \\
\hline & & Difference $(I-J)$ & Std. Error & & Lower Bound & Upper Bound \\
\hline \multirow[t]{3}{*}{1} & 2 & -.41184 & .29842 & .520 & -1.2185 & .3948 \\
\hline & 3 & $-.55705^{*}$ & .19067 & .024 & -1.0589 & -.0552 \\
\hline & 4 & $-.57150^{*}$ & .17996 & .011 & -1.0436 & -.0994 \\
\hline \multirow[t]{3}{*}{2} & 1 & .41184 & .29842 & .520 & -.3948 & 1.2185 \\
\hline & 3 & -.14522 & .27965 & .954 & -.9119 & .6214 \\
\hline & 4 & -.15966 & .27246 & .935 & -.9106 & .5913 \\
\hline \multirow[t]{3}{*}{3} & 1 & $.55705^{*}$ & .19067 & .024 & .0552 & 1.0589 \\
\hline & 2 & .14522 & .27965 & .954 & -.6214 & 9119 \\
\hline & 4 & -.01444 & .14675 & 1.000 & -.4036 & .3748 \\
\hline \multirow[t]{3}{*}{4} & 1 & $.57150^{*}$ & .17996 & .011 & .0994 & 1.0436 \\
\hline & 2 & .15966 & .27246 & .935 & -.5913 & .9106 \\
\hline & 3 & .01444 & .14675 & 1.000 & -.3748 & .4036 \\
\hline
\end{tabular}

Source: Authors' own compilation

Notes: * .05 level is taken for significance in the Mean Difference

\section{Conclusion}

The aim of the study was to evaluate how firm size may impact network relationships in case of KIBS firms in India. Firm size has been measured in terms of number of employees while network relationships include those with suppliers, select competitors, investors and customers. 
Network Relationships in Knowledge Based Service Firms: Variance in Terms of Firm Size

Firms do have strong network relationships with their customers (NC) as reflected in the mean score of $\mathrm{NC}$ being 4.01 as firms regularly communicate with their customers. It is observed in the study that there is a significant difference between NC of firms with more than 10000 employees (Group 4) as compared to firms with upto 100 employees (Group 1). At the same time there are no differences across Group 2 (101 to 1000 employees), Group 3 (1001 to 10000 employees) \& Group 4. This shows that as knowledge based firms achieve a size of 100 plus employees they achieve significantly strong network relationships with their clients.

It is also observed that the mean score of network relationship with suppliers (NS) is 3.60 thus showing that supplier relationships are not as strong as customer relationships in knowledge based firms. Also it is observed that there are no differences across different firm sizes in terms of NS. It may be noted that although suppliers may play a critical role in manufacturing firms and form part of critical supply chains, the role of suppliers in knowledge based firms may be more as a supporting function.

Knowledge based firms may even develop network relationships with select competitors (NCOM) as they bid for large projects which require multiple vendors or become a part of a global alliance. The mean score of NCOM is 2.78 which indicates that in knowledge based firms competitor relationships are weak. The score of 3.56 for the item NCOM1 indicates that competitors could be a source of new ideas. In the study it is found that NCOM does not vary with firm size.

Network relationships with investors (NI) may provide crucial knowledge and market insights to firms particularly regarding the competitive scenario in KIBS. The study finds the mean score of NI is 3.77 which indicates that knowledge firms have fairly strong investor relationships and regularly communicate with their investors.

There is a significant difference in NI of firms with more than 10,000 employees as compared to NI of firms upto 100 employees. Similarly, there is a significant difference in NI of firms with 1001 to 10000 employees as compared to NI of firms with upto 100 employees. Also there are no significant differences across other groups. This may be explained in terms of the fact that knowledge based service firms employ high end knowledge based professionals and such firms achieve a sufficient scale as they cross the threshold of 100 employees.

In many such firms which have grown from startups, strategic investors may play a critical role in mentoring and formulating firm strategy. Such firms achieve strong network relationships with both their investors and customers. Investors may provide critical knowledge about competitive scenario while customers may provide market insights as many times service delivery may require frequent and in-depth interactions with clients.

\section{References}

Aguilar-Fernández, M.,E., \& José Ramon Otegi-Olaso. (2018). Firm size and the business model for sustainable innovation. Sustainability, 10(12), 4785.

Amara, N., Landry, R. \& Doloreux, D. (2009). Patterns of innovation in knowledge-intensive business services. The Service Industries Journal, 29(4), 407-430.

Arias, J. T. G. (1995). Do networks really foster innovation? Management Decision, 33(9), 52-56. 
Amit Sareen and Sharadindu Pandey

Bandick, R. (2020). Global sourcing, firm size and export survival. Economics, 14(18), 1-29.

Barile, S., Lusch, R., Reynoso, J., Saviano, M., \& Spohrer, J. (2016). Systems, networks, and ecosystems in service research. Journal of Service Management, 27(4), 652-674.

Bartlett, M. S. (1950). Tests of significance in factor analysis. British Journal of Statistical Psychology, 3(2), 77-85.

Chang, Y., Linton, J.D. \& Chen, M. (2012). Service regime: an empirical analysis of innovation patterns in service firms. Technological Forecasting \& Social Change, 79, 1569-1582.

Demirkan, I. (2018). The impact of firm resources on innovation. European Journal of Innovation Management, 21(4), 672-694.

Chesbrough, H. (2011). Bringing open innovation to services. MIT Sloan Management Review, 52(2), 85-90.

Freel, M. S. \& Harrison, R. T. (2006). Innovation and cooperation in the small firm sector: evidence from Northern Britain. Regional Studies, 40(4), 289-305.

den Hertog, P. (2000). Knowledge-intensive business services as co-producers of innovation. International Journal of Innovation Management, 4(4), 491-528.

Henke Jr., J.W. \& Zhang, C. (2010). Increasing supplier driven innovation. MIT Sloan Management Review, Winter 2010, 51(2), 41-46.

Huggins, R. (2010). Network resources and knowledge alliances: Sociological perspectives on inter-firm networks as innovation facilitators. International Journal of Sociology and Social Policy, 30(9/10), 515-531.

Inkpen, A.C., \& Tsang, E.W.K. (2005). Social capital, networks and knowledge transfer. Academy of Management Review, 30(1), 146-165.

Kaiser, H. F. (1974). An index of factorial simplicity. Psychometrika, 39(1), 31-36.

Laforet, S. (2012). Organizational innovation outcomes in SMEs: effects of age, size, and sector. Journal of World Business, 599, 1-13.

Landry, R., Amara, N., \& Doloreux, D. (2012). Knowledge-exchange strategies between KIBS firms and their clients. The Service Industries Journal, 32(2), 291-320.

Marom, S., Lussier, R. N., \& Sonfield, M. (2019). Entrepreneurial strategy: The relationship between firm size and levels of innovation and risk in small businesses. Journal of Small Business Strategy, 29(3), 33-45.

Michel, S., Brown, S.W., \& Gallan, A.S. (2008). Service-logic innovations: How to innovate customers not products. California Management Review, 50(3), Spring 2008.

Miotti, L. \& Sachwald, F. (2003). Co-operative R\&D: Why and with whom?: An integrated framework of analysis. Research Policy, 32(8), 1481-1499.

Nicolajsen, H. W. \& Scupola, A. (2011). Investigating issues and challenges for customer involvement in business services innovation. Journal of Business \& Industrial Marketing, 26(5), 368-376.

Nidumolu, R., Ellison, J., Whalen, J., \& Billman, E. (2014). The Collaboration Imperative: New Partnership models can protect the environment and create value for everyone. Harvard Business Review, April 2014.

Pallant, J. (2013). SPSS Survival Manual. McGraw-hill education (UK).

Park, C. \& Lee, H. (2018). Early stage value co-creation network-business relationships connecting high-tech B2B actors and resources: Taiwan semiconductor business network case. Journal of Business \& Industrial Marketing,33(4), 478-494.

Pires, C.P., Sarkar, S., \& Carvalho, L. (2008). Innovation in services - how different from manufacturing?' The Service Industries Journal, 28(10), 1339-1356. 
Network Relationships in Knowledge Based Service Firms: Variance in Terms of Firm Size

Pittaway, L., Robertson, M., Munir, K., Denyer, D., \& Neely, A. (2004). Networking and innovation: A systematic review of the evidence. International Journal of Management Reviews, 5/6(3\&4), 137-168.

Rusanen, H., Halinen, A., \& Jaakkola, E. (2014). Accessing resources for service innovation-the critical role of network relationships. Journal of Service Management, 25(1), 2-29.

Santos-Vijande, M. L., González-Mieres, C. \& López-Sánchez, J. Á. (2013). An assessment of innovativeness in KIBS: implications on KIBS' co-creation culture, innovation capability, and performance. Journal of Business \&Industrial Marketing, 28(2), 86-102.

Sareen, A. \& Pandey, S. (2015). Measuring networking and innovation in knowledge intensive business services. International Journal of Management Research, 6(1), 18-32.

Sareen, A. \& Pandey, S. (2014). The effect of network relationships on innovation in knowledge intensive business services. AIMA Journal of Management \& Research,8(3/4).

Sundbo, J. (1997). Management of innovation in services. The Services Industries Journal, 17(3), 432-455.

Tang, G., Park, K., Agarwal, A., \& Liu, F. (2020). Impact of innovation culture, organization size and technological capability on the performance of SMEs: The case of china. Sustainability, 12(4), 1355.

Tether, B.S. (2005). Do services innovate (differently)? Insights from the European innobarometer survey. Industry and Innovation, 12(2), 153-184.

Walters, D. \& Rainbird, M. (2007). Cooperative innovation: a value chain approach. Journal of Enterprise Information Management, 20(5), 595-607.

Wang, J., Zhang, Y., \& Goh, M. (2018). Moderating the role of firm size in sustainable performance improvement through sustainable supply chain management. Sustainability, 10(5), 1654.

Wulf, A. \& Butel, L. (2017). Knowledge sharing and collaborative relationships in business ecosystems and networks. Industrial Management \& Data Systems, 117(7), 1407-1425.

$\mathrm{Xu}, \mathrm{Z}$. , Lin, J., \& Lin, D. (2008). Networking and innovation in SMEs: Evidence from Guangdong province, China. Journal of Small Business and Enterprise Development, 15(4), 788-801.

Yu, G. J., \& Lee, J. (2017). When should a firm collaborate with research organizations for innovation performance? The moderating role of innovation orientation, size, and age. Journal of Technology Transfer, 42(6), 1451-1465.

Yung-Chang, H. (2019). Exploring service innovation and value creation: The critical role of network relationships. Journal of Management and Organization, 25(1), 4-25.

Zeng, S.X., Xie, X.M., \& Tam, C.M. (2010). Relationship between cooperation networks and innovation performance of SMEs. Technovation, 30, 181-194. 